\title{
Determination of Effective Schools in Undergraduate School State Islamic University of North Sumatera
}

\author{
Indra Jaya \\ State Islamic University of North Sumatera, North Sumatera, Indonesia \\ indrajaya@uinsu.ac.id
}

\begin{abstract}
Effective schools at the undergraduate level are very decisive educational institutions in producing future generations of scholars. Several strong factors can change tertiary institutions, such as undergraduate schools at the North Sumatra State Islamic University into effective schools. These factors are a commitment that is owned by the organizers, the organizer's trust, interpersonal communication, leadership and organizational culture that is in it.
\end{abstract}

Keywords: Undergraduate school; effectiveness.

\section{Introduction}

Various phenomena indicate that undergraduate schools at North Sumatra State Islamic University have not been effective. This condition can be seen starting from the number of students who are not proportional to the number of teaching staff with a ratio of 1: 200, facilities and infrastructure owned, the level of service to the level of curriculum being taught. At this level of output produced is detected is not optimal due to the inefficiency that occurs in the graduate school of the State Islamic University of North Sumatera.

Furthermore, looking at the level of lecturer quality, there are still many found in each study program that still uses outside teaching staff with temporary lecturer status who do not have much teaching experience, also found from a number of senior lecturers who hold the professors degree still rely on assistants who have just completed their degrees. Postgraduate education (S2). Such conditions are thought to affect the atmosphere of learning in the classroom less effectively to boost targeted output.

If connected with the phenomenon of lack of effectiveness in undergraduate school at the State Islamic University of North Sumatra, both in terms of students, faculty, administrative personnel, infrastructure, and service system in undergraduate school at State Islamic University of North Sumatra, as already mentioned, it is to increase its effectiveness can be built a effectiveness model of undergraduate school at the State Islamic University of North Sumatra with variables that influence it, namely, leadership, organizational culture, communication, trust and commitment. This model should be based on the purpose of the transcendent that effective school-based character in question is the transcendence. This character-based transcendence means that all variables that affect the effective school namely school culture, leadership, communication, trust, and commitment are also based on the character of this transcendence.

\subsection{Effective School}

\section{Review of Literature}

Taylor (1990: 55), an effective school as a school that organizes and utilizes all of its resources to ensure all students can learn essential curriculum material at school. Hoy and 
Miskel (1998: 7) adopted this model in schools by creating a model of social systems in schools

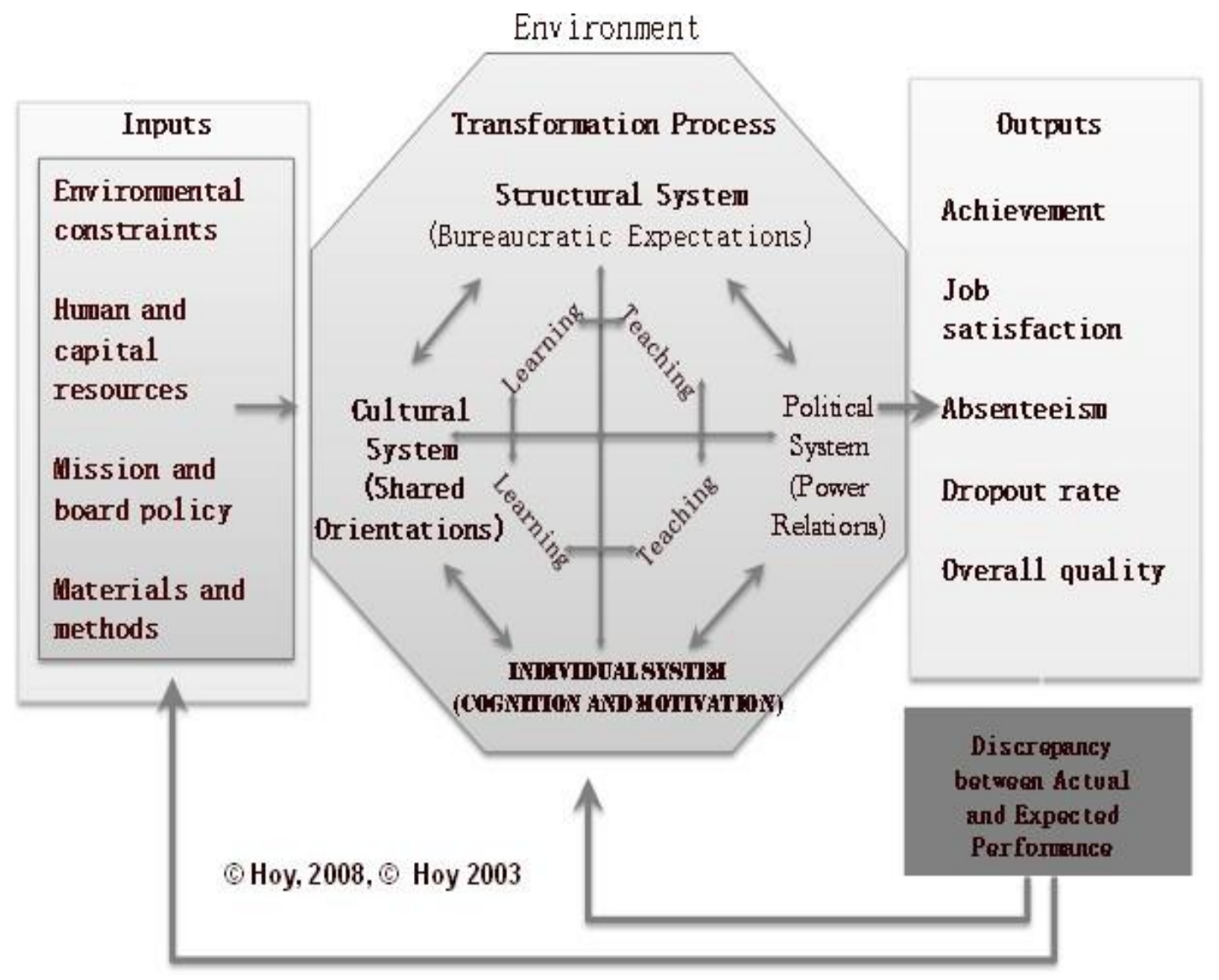

Figure 1. Hoy Miskel

Further explained Hoy and Miskel (1998: 19) six dimensions characterize how to make people as individuals or groups effective in organizations. namely, (1) the foundation of behavior in this system model is trust, community and meaning, (2) managerial orientation caring and compassion, (3) psychological orientation human resources ownership (4) Individual drive at work is self-motivation, (5) achievement of needs individuals are very broad and not limited (6) performance achievements are determined by sincerity and commitment to achieve work goals.

Sagala (2005: 77) the characteristics of effective schools is closely related to the school management, leadership, commitment, consistency with the program objectives and targets of school, internal and external strategic environment, expectations, school climate and the role of government. According to Slocum (2009), several factors influence an organization to be effective including competence consisting of knowledge, skills, and abilities. The types of competencies are self, communication, diversity, ethics, across cultures, teams, and change. 


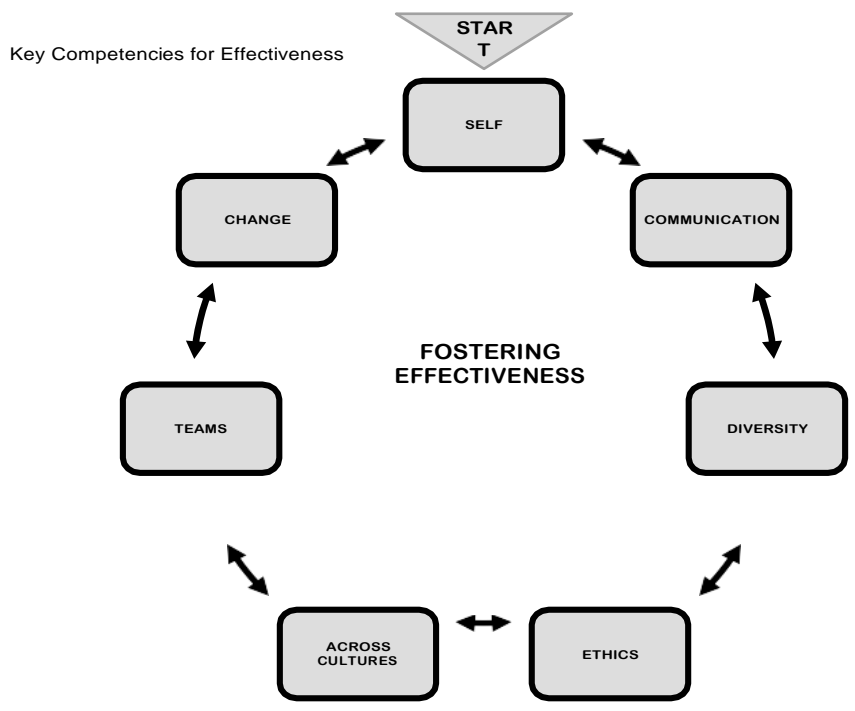

Figure 2. Slocum

\subsection{Commitment}

Taylor Peplau and Sears (1990: 350), commitment is all the power (attraction and barrier) that keeps a person in a relationship. Luthans (2006: 249) commitment is defined as

(1) a strong desire to remain as a member of a particular organization, (2) a desire to strive according to the wishes of the organization, and (3) certain beliefs and acceptance of organizational values and goals. In other words, commitment is an attitude that reflects employee loyalty to the organization and the ongoing process by which members of the organization express their concern for the organization and its continued success and progress.

Arikunto (2000: 135) commitment to the task is not just involvement, but it shows someone's willingness to be actively involved in an activity with high responsibility. Hoy and Miskel (1998: 100) individuals who have a high commitment to the task usually show loyalty and professional skills.

Taylor, Peplau, and Sears (2009: 350-3510) noted three factors that influence commitment, namely: (1) The power of attraction. Commitment is influenced by the power of attraction in certain relationships. In other words, the commitment would be stronger if high satisfaction. This component is called "component personnel" because it refers to the desire of individuals to maintain or improve the relationship, (2) The value and moral principles. Commitment is influenced by moral values and principles that individuals should remain in an organization. Commitment values and moral principles are based on the feeling of obligation and responsibility, and (3) The negative force or obstructions. Commitment is based on the negative force or obstructions that cause individuals will feel the loss will leave the organization.

Indeed, the commitment is multidimensional as described Luthan (2006: 249-250) as follows: (1) affective commitment, (2) continuation of the commitment and (3) normative commitment. Affective commitment is the employee's emotional attachment, identification, and involvement in the organization. Continuation commitment is a commitment based on losses related to the discharge of employees from the organization. This may be due to loss of seniority for promotion or benefits. Normative commitment is a feeling of obligation to remain in the organization because it must be so, the action is the right thing to do.

Based on the description and theory put forward by Schatz, Luthans, Sah understanding, 
Wahjusumidjo and Hoy Miskel it can be concluded that the commitment referred to in this study is the attachment of feeling felt called to his soul to carry out the task with full responsibility and always fostering sincerity with a contract or work contract which shows a set of attitudes. The formulation of indicators of commitment to the task are: (1) Caring for the task, (2) Willingness to remain as a member, (3) Acceptance of organizational values.

\subsection{Trust}

Trust is a person's willingness to rely on others where we have confidence in him. Trust is a mental condition based on a person's situation and social context. When a person makes a decision, he will prefer decisions based on the choices of people he can trust more than the less trusted. (Morgan, Robert M and Shelby D Hunt: Journal of Marketing. Vol. 58, 1994. p. 20-38)

Trust by Johnson \& Johnson (2009) is an aspect of a relationship and constantly changing and is the basis for establishing and maintaining interpersonal relationships. Henslin in Kim (2003: 157-167) saw trust as expectations and confidence of individuals to the reliability of others. The foundation of trust involves respecting one another and accepting differences. Individuals who have high trust tend to be preferred, happier, regarded as the closest person than individuals who have low trust. Based on some of the notions stated above, the conclusion is drawn that the definition of trust is a basic element for the creation of a good relationship between the two parties which contains the expectations and beliefs of individuals about one's reliability.

According to Rousseau et al (1998: 303-404) trust is a psychological area that is a concern for accepting what it is based on expectations of good behavior from others. Furthermore, according to Mayer et al (1995: 709-734) consumer confidence is defined as the willingness of the parties to accept the risk of the other party action based on the hope that the other party will be an important activity for those who believe, regardless of the ability to supervise and control the actions of the parties trusted. Meanwhile, according to Pavlou (2002: 667-675) trust as an assessment of one's relationship with others who will conduct certain transactions in line with expectations in an environment of uncertainty.

Based on the description that has been stated by Johnson \& Johnson, Henslin, Rousseau et al, Mayer et al, Falcone \& Castelfranci and Copiah, according to the researchers' analysis, the intended belief in the research is to include a picture of a good relationship between the two parties which contains the hopes and beliefs of individuals on the reliability of a person. Indicators of trust measurement are (1) confidence in others, (2) positive thinking about others, (3) Opening distance from others, (4) Providing opportunities for others to act, and (5) improving social relationships with others.

Interpersonal CommunicationSarah Trenholm (1991: 8) at the most general level, communication is a process of treating information (a process of acting on informatory). Baran (2004: 4) explains communication is the process of moving messages from a source to the recipient of the message. More explained Baran (2004: 5) defines interpersonal communication is the process of communication between two people or several people.

Stephen W. Littlejohn (1991: 17) interpersonal communication is communication between two people who are usually in the form of face-to-face communication and personal situation settings. Stoner and Freeman (1992: 149) interpersonal communication is a process in which people are trying to acquire the same sense through messaging. Robbins (2004: 213) how each individual carrying out the interpersonal communication, there are three of them:

(1) oral communication, in the form of speeches, one conversations and group discussions, and its advantages are speed and feedback they produce, (2) a written 
communication, in the form of memos, letters, e-mails, facebook, facsimile sending, periodical reports of organizations, announcements on bulletin boards, or other devices sent via written words or symbols, and (3) nonverbal communication, in the form of body movements, intonation or pressure on words.

Thoha (2003: 190) interpersonal communication is the process of delivering news done by someone and the receipt of the news by other people or small groups of people, with an immediate result and feedback. Rivai (2007: 99) interpersonal communication-oriented behavior until the emphasis is on the information process, from one person to another. This is similar to what was stated by Muhammad (2007: 59) interpersonal communication is a process of exchanging information between a person with at least one other or generally between two people who can immediately known it back. From the communication that occurs between two or more people, it will produce four forms of interpersonal communication as explained by Redding in Muhammad (2007: 159) that interpersonal communication can be grouped into four groups, namely: (1) intimate interaction. Intimate interactions include communication between good friends, married couples, family members, and people who have strong emotional ties. Within organizations, this relationship is developed in the form of informal communication, (2). social conversation is an interaction to please someone simply with little talk. The conversation is usually not so noticeable in-depth, (3) questioning or examination is the interaction between a person who is in control, request or even demand information than others; and (4) interview is a form of interpersonal communication in which two people engage in a question and answer conversation.

Stephen W. Littlejohn (1991: 17) interpersonal communication is communication between two people who are usually in the form of face-to-face communication and personal situation settings. Stoner and Freeman (1992: 149) interpersonal communication is a process in which people try to get the same understanding through sending messages.

Taking into account the humanistic and pragmatic models put forward by Devito and theories from Thoha, Stoner \& Freeman, interpersonal communication in this study is the ability to strive to gain understanding and establish relationships between communicating parties which include (1) openness (2) empathy, (3) mutual support, (4) others oriented.

LeadershipTerry (1983: 327) leadership is a relationship in which one person namely a leader influences the other party to work together voluntarily to carry out tasks related to achieving what the leader wants. Leadership is a process of influencing others to achieve goals, as stated by Hersey and Blanchard (1988: 83) "Leadership is the activity of influencing people to strive willingly for group objectives".

Yukl (2009: 8) leadership is a process to influence others to understand and agree with what needs to be done and how the task is carried out effectively, as well as a process to facilitate individual and collective efforts to achieve shared goals. Gribbin, A (1992: 9) "Leadership can be described as a process of influence on a group in an apartelle situation, at a given point of individual time, and in a specific set of organizational organizational objectives, giving them the experience or helping to attain the common objectives and satisfaction with the type of leadership provide ".

According to Koontz et al (1984: 306) leadership is "We define leadership as influencing, the art organization process of influencing people so that will thrive willingly and enthusiastically toward the achievement of group goals. This concept can be charged to imply not only willingness to work but also willingness to work with deal and confidence. Davis (1972: 140): "It has been pointed out that an organization consists of a group of individuals cooperating under the direction of executive leadership toward the accomplishment of certain common objectives". 
Fiedler and Charmers (1974: 52) the main problems of leadership can be divided into three main problems, namely: (1) how a person can become a leader, (2) how leaders behave, and (3) what makes a leader successful. In connection with this Wahyusumidjo (2002: 19) leadership which consists of various approaches, in essence, is an attempt to answer or provide solutions to the problems contained in these three problems. Almost the entire leadership of research can be grouped into four different approaches, namely the influence of authority, traits, behavioral and situational. Based on the natural approach, the success of a leader is not only influenced by personal traits but is also determined by the personal skills (leaders). This is in line with the opinion of Yukl (2009: 5) which states that the personal qualities and skills of a leader play a role in the success of a leader.

Leadership in this study refers to the prophetic leadership proposed by adh-Dzakiey and coupled with the theory put forward by Terry and Good. Based on the description above, leadership is the ability to influence based on beliefs and tenets of religion that brings mission moral progress and the spiritual, embed motifs higher life and the great form of the quality of goodness, beauty, generosity and refinement indicator (1) Able to motivate others, (2) Ability to feedback, (3) Ability to participate, (4) Delegating tasks, (5) Control.

\subsection{School Culture}

Hadiyanto (2004: 153) school culture is the final product of interaction between groups of students in schools, teachers and administrative staff (administrators) who work to strike a balance between the organizational (school) dimension and the individual dimension. Sergiovanni and start in Hadiyanto (2004: 155) explains that the school culture is a characteristic that exists, which describes the characteristics of a psychological than a particular school, which is to differentiate one school from other schools, affecting the behavior of teachers and learners and the psychological feeling that owned by teachers and students in certain schools.

Moedjiarto (2002: 28) quotes Larsen as defining school culture as a norm, hope, and trust of personnel involved in school organizations that can provide impetus for action that leads to high student achievement. In line with the development of school culture, Klob in Komariah (2006: 46) noted 7 dimensions of organizational culture that can be adapted for school culture, namely: (1) conformity, if in an organization many rules must be obeyed by staff/employees whereas the rule has no relevance to the performance of the work. Such an organization is said to have low conformity and conversely is called high confirmation, (2) responsibility, if in an organization all decision-makers are carried out by one person at the helm, such a working climate is a climate with low responsibilities, because basically subordinate had never been given the opportunity of having the responsibility, (3) remuneration (reward), if an organization all people feel that even if they are doing well, but did not get an award or remuneration for but if making small mistakes punished. The work climate is a work climate with low rewards, (4) group spirit, if in an organization people are suspicious of each other, difficult to trust each other, and there is no sense of grouping such a work climate is a work climate with a low team spirit (5) clarity, if, in an organization with unclear work procedures, people feel they do not know for certain which responsibilities and authority, such a work climate is a work climate with low clarity, (6) standards, provisions stipulated about the quality of the work done by its members, and (7) leadership, if in an organization there is no perceived guidance and attention from superiors to the performance of the people in it, the sustainability of the organization runs in its routine so that such a climate results in a work climate with leadership low.

Referring to the theories of Startt, Larsen, Mulyasa, Hadiyanto and Pidarta the school culture referred to in this study is a characteristic that describes the psychological 
characteristics of a particular school, which distinguishes a school from another school, influencing the behavior of teachers and students and students is a psychological feeling that teachers and students have in a particular school. In this case, the dimensions that become indicators for examining school culture include the establishment of good discipline, the presence of togetherness, appreciation for work and communication.

\section{Research Method}

This research was conducted at the undergraduate school at UIN-SU North Sumatra Province and carried out in February 2015 to October 2016. The sample in this study were all permanent lecturers at the undergraduate school at the State Islamic University of North Sumatra, totaling 419 lecturers spread across 38 Study Programs/majors under the guidance of 8 (eight faculties). This study analyzes the effect of one variable on other variables, both direct and indirect influences, namely: (Undergraduate School Culture (X1), Leadership (X2) and Interpersonal Communication (X3) as exogenous variables is the variable Belief (X4), Commitment (X5 ) and Effectiveness of Undergraduate Schools (X6) The analysis technique used by PATH ANALYSIS with the LISREL program version 8.30 The research analysis schemes offered are as follows:

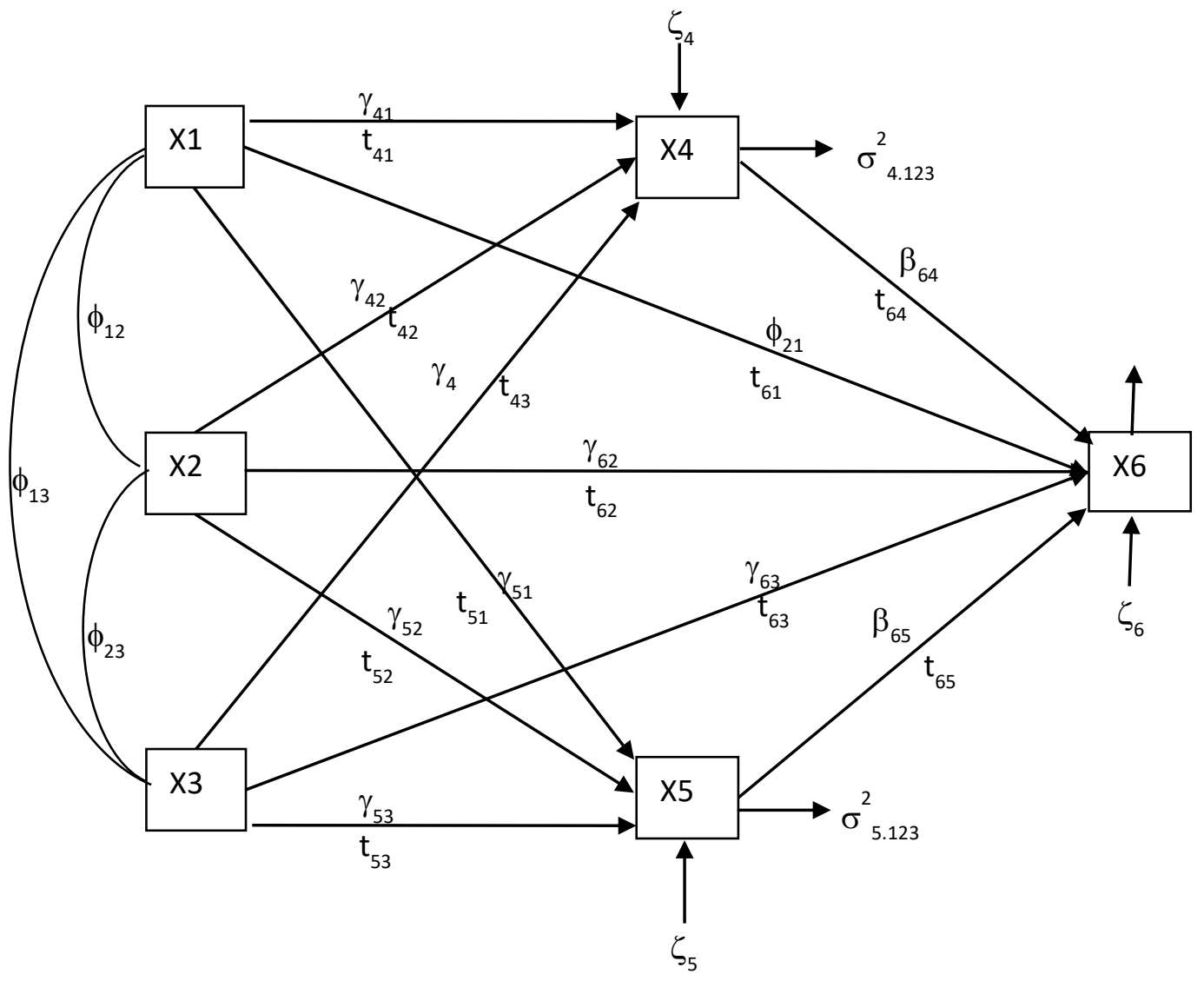




\section{Discussion}

The findings of the research results can be described as follows:

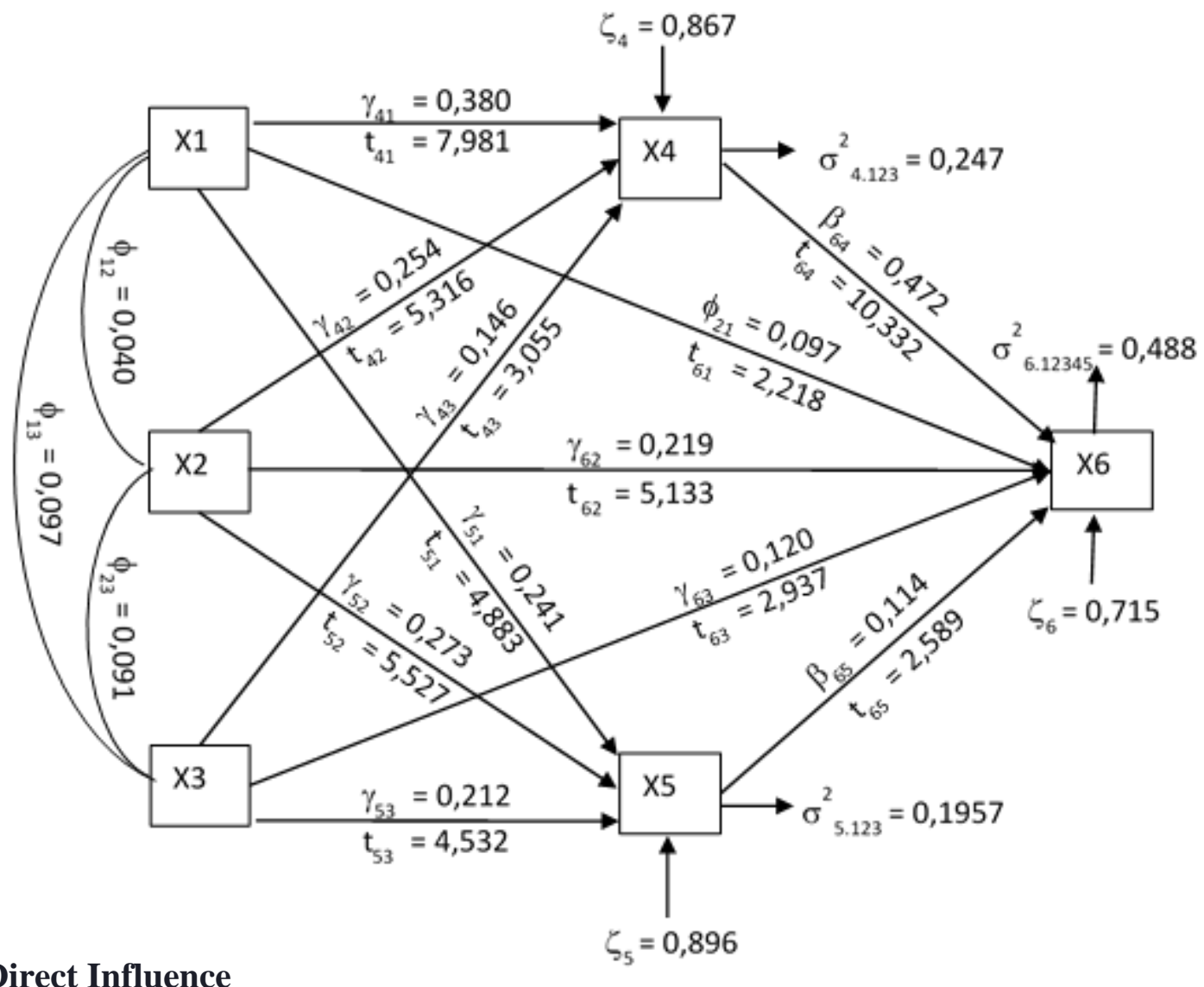

\subsection{Direct Influence}

The results of the statistical analysis obtained that the coefficient value of the influence of undergraduate school culture, leadership and interpersonal communication respectively on trust amounted to 0,$380 ; 0,254$ and 0,146 with the calculated coefficient value of 7,981; 5,316 and 3,055 . For the value of the coefficient table at the significance level of $95 \%$ and $99 \%$ respectively 1,967 and 2,591. By comparing the value of the t-count coefficient with $\mathrm{t}$ - table, it can be said that the influence exerted by the undergraduate school culture, leadership and interpersonal communication variables on each of the beliefs is declared significant. Structural equation models that can take the form are:

$$
f\left(X_{4}\right)=0,380 X_{1}+0,254 X_{2}+0,146 X_{3}
$$

The relationship between undergraduate school culture, leadership and interpersonal communication with commitment. The correlation coefficients were 0,$255 ; 0,303$ and 0,241 with each coefficient value t-test amounting to 5,812; 5,792 and 4,532 are stated to be very significant. Based on the results of the statistical analysis it was found that the coefficient value of the influence of undergraduate school culture, leadership and interpersonal communication respectively towards commitment amounted to 0,$241 ; 0,273$ and 0,212 with coefficient values ttest each for 4,883; 5,527 and 4,288. For the value of the t-table coefficients at the significance level of $95 \%$ and $99 \%$ respectively 1,967 and 2,591. By comparing the value of the coefficient of t-test with t-table, it can be said that the influence exerted by the undergraduate culture, leadership and interpersonal communication variables of each of the commitments is declared 
significant. Structural equation models that can take the form are:

$$
f\left(X_{5}\right)=0,241 X_{1}+0,273 X_{2}+0,212 X_{3}
$$

The relationship between undergraduate school culture, leadership, interpersonal communication, trust and commitment with the effectiveness of undergraduate schools. The correlation coefficients are 0,$323 ; 0,402 ; 0,253 ; 0,262$ and 0,369 with t-test coefficient values of 6,$225 ; 8,016 ; 4,766 ; 14,644$ and 7,249 were declared very significant. Based on the results of the statistical analysis it was found that the coefficient value of undergraduate school culture, leadership, interpersonal communication, trust and commitment of each to the effectiveness of undergraduate schools was 0,$097 ; 0,219 ; 0,120 ; 0,472$ and 0,114 with the t-test coefficient value of 2,$218 ; 5,133 ; 2,937 ; 10,332$ and 2,589 . For the value of the t-table coefficients at the significance level of $95 \%$ and $99 \%$ respectively 1,967 and 2,591.

By comparing the value of the t-test coefficient with the t-table it can be said that the influence exerted by undergraduate school culture variables and / or commitments is declared significant. As for leadership, interpersonal communication, belief in the effectiveness of undergraduate schools has a very significant influence. Structural equation models that can take the form are:

\section{$f\left(X_{6}\right)=0,097 X_{1}+0,219 X_{2}+0,120 X_{3}+0,472 X_{4}+0,114 X_{5}$}

\subsection{Indirect Effects}

The indirect influence of undergraduate school culture $\left(\mathrm{X}_{1}\right)$ through trust $\left(\mathrm{X}_{4}\right)$ and leadership $\left(\mathrm{X}_{5}\right)$ on effective schools $\left(\mathrm{X}_{6}\right)$ was 0,207 with a t-test coefficient value of 6,72 . because the t-table coefficient value for $\alpha_{(0,05: 329)}=1,966$ and t-table for $\alpha_{(0,01: 329)}=2,588$ is greater than the value of the t-test coefficient. Thus, the indirect influence of undergraduate school culture $\left(\mathrm{X}_{1}\right)$ through trust $\left(\mathrm{X}_{4}\right)$ and commitment $\left(\mathrm{X}_{5}\right)$ towards effective schools $\left(\mathrm{X}_{6}\right)$ is stated to be very significant. With a contribution of $(0,207)^{2} \times 100 \%=4,28 \%$.

The indirect influence of leadership $\left(\mathrm{X}_{2}\right)$ through trust $\left(\mathrm{X}_{4}\right)$ and leadership $\left(\mathrm{X}_{5}\right)$ on the effectiveness of undergraduate schools $\left(\mathrm{X}_{6}\right)$ was 0,151 with a t-test coefficient value of 5,28. Therefore the t-table coefficient value for $\alpha_{(0,05: 329)}=1,966$ and t-table for $\alpha_{(0,01: 329)}=2,588$ is greater than the t-test coefficient value. Thus, the indirect influence of leadership $\left(\mathrm{X}_{2}\right)$ through trust $\left(\mathrm{X}_{4}\right)$ and leadership $\left(\mathrm{X}_{5}\right)$ on the effectiveness of undergraduate schools $\left(\mathrm{X}_{6}\right)$ is stated to be very significant. With a contribution of $(0,151)^{2} \times 100 \%=2,29 \%$.

\subsection{Total Influence}

The effect of total undergraduate school culture variables $\left(\mathrm{X}_{1}\right)$ on the effectiveness of undergraduate schools $\left(\mathrm{X}_{6}\right)$ was 0,3049 , with a t-test coefficient value of 6,66 . Therefore the ttable coefficient value at pada $\alpha_{(0,05: 329)}=1,966$ and $\mathrm{t}$-table at $\alpha_{(0,01: 329)}=2,588$ greater than the t-test value, thus, the total effect of undergraduate school culture variables $\left(\mathrm{X}_{1}\right)$ to the effectivity of undergraduate school effectiveness $\left(\mathrm{X}_{6}\right)$ was stated to be very significant, with a contribution made $(0,3049)^{2} \times 100 \%=9,29 \%$.

The influence of the total leadership variable $\left(\mathrm{X}_{2}\right)$ on the effectiveness of undergraduate schools $\left(\mathrm{X}_{6}\right)$ was 0,3708 , with a t-test coefficient of 8,07 . Therefore the t-table coefficient value at $\alpha_{(0,05: 329)}=1,966$ and t-table at $\alpha_{(0,01: 329)}=2,588$ is greater than the t-test value, thus, the effect of the total leadership variable $\left(\mathrm{X}_{2}\right)$ to the variable effectiveness of undergraduate schools $\left(\mathrm{X}_{6}\right)$ expressed very significant, with contributions made at $(0,3708)^{2} \times 100 \%=13,75 \%$. 
The effect of total interpersonal communication variables $\left(\mathrm{X}_{3}\right)$ on the effectiveness of undergraduate schools $\left(\mathrm{X}_{6}\right)$ was 0,2140 , with a t-test coefficient value of 4,66 . Therefore the $\mathrm{t}-$ table coefficient value at $\alpha_{(0,05: 329)}=1,966$ and t-table at $\alpha_{(0,01: 329)}=2,588$ greater than the $\mathrm{t}$ - test value, thus, the total effect of interpersonal communication variables $\left(\mathrm{X}_{3}\right)$ to the variable effectiveness of undergraduate schools $\left(\mathrm{X}_{6}\right)$ expressed very significant, with a contribution of $(0,2140)^{2} \times 100 \%=4,58 \%$.

Summary results of the calculation of the direct influence, indirect influence and effect as well as the total contributions made by the exogenous variables on the endogenous variables of the respective sub-structure of the model can be seen in the following table:

Tabel 1. Summary of Results of Direct Effect Analysis, Indirect Effect, Total Effect, Determination and Residue

The coefficient of direct influence, indirect effect, total effect and contribution

Total

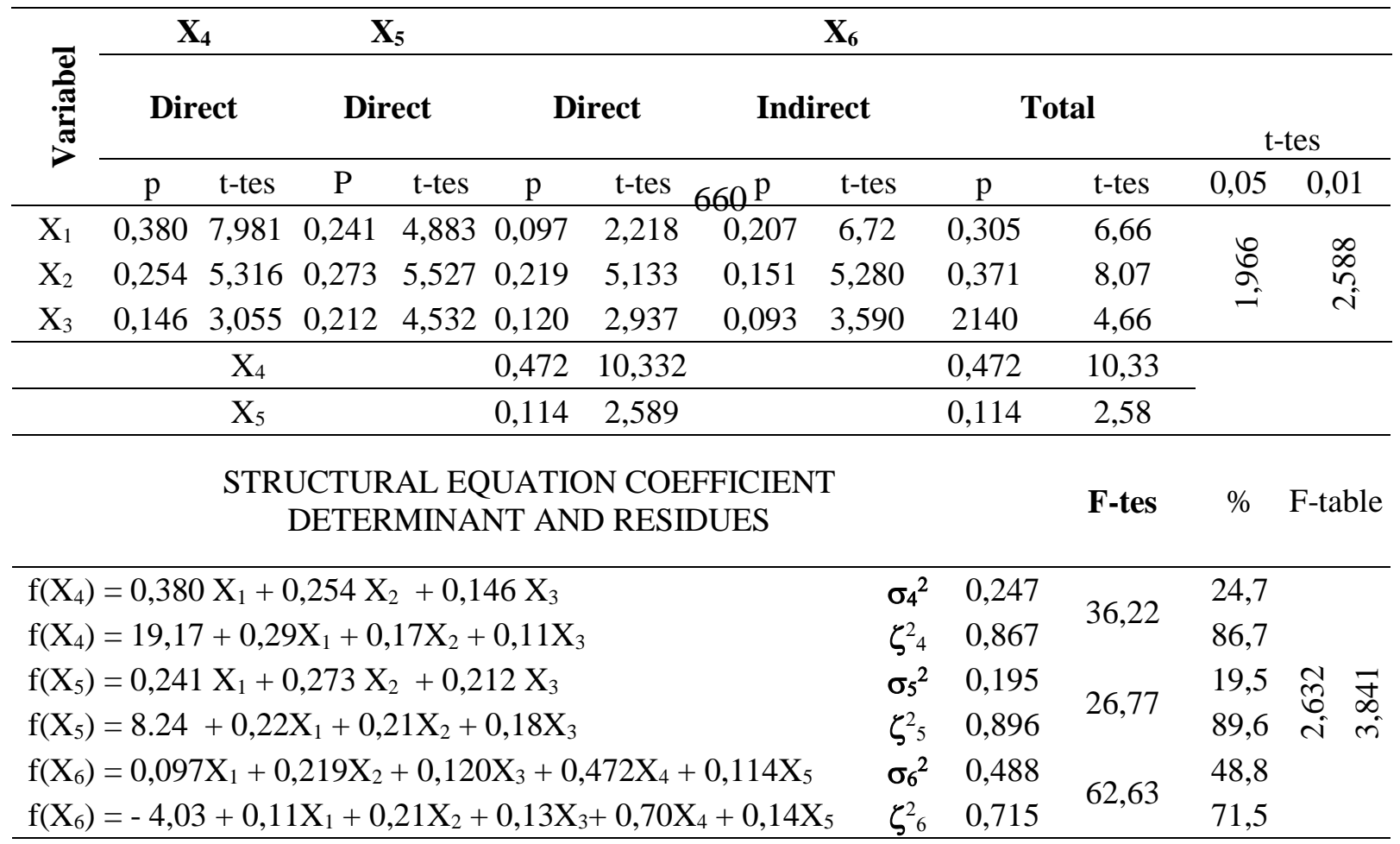

\subsection{Implications of Research Results}

Five main factors are supporting or prerequisites for developing undergraduate school effectiveness to improve the quality of output, namely strong leadership, clarity of study program/department vision, maintaining a climate of security and student order, monitoring student progress from academic advisors, and high expectations from all undergraduate school organizer component.

Strong leadership; The quality of leadership greatly influences the achievement of an effective undergraduate school. Undergraduate school leaders / Rector in this case as formal and factual leaders of an undergraduate school must be able to collaborate and synergize components of the organizers such as leaders in the Faculties / Deans, lecturers, students, and 
all employees/staff of the undergraduate school. Besides, the chancellor of an undergraduate school must also be able to maximize the infrastructure needed for an effective undergraduate school.

Rector's undergraduate school should be able to be an example of integrity that is exemplary by all the organizers of the graduate school at State Islamic University of North Sumatra. The integrity of a Rector greatly affects the quality of the organizers of the institution he leads. With good integrity, a leader in undergraduate school's rector will be adhered to and respected by the organizers of the lead component so data create organizational environments that undergraduate school and conducive. Undergraduate school chancellors should also focus on supervising every activity that takes place in the undergraduate school environment.

Clarity of school vision and mission; Undergraduate schools need to have a clear vision and mission starting at the level of study programs/departments, faculties, and even university level because an effective undergraduate school will move according to the vision translated into several missions that will be implemented to achieve the goals of implementing an effective school. With a clear vision and mission, the undergraduate school will move in a directed direction. Starting from the rector, the dean, and head of the department will be easier to translate and carry out the mission and vision in the work program.

At the beginning of his tenure, the organizers of the graduate school starting from the rector, deans, and department chairman is expected to socialize with good vision and mission to the faculty and staff employees as well as students. Then the undergraduate school organizers work hand in hand to apply the vision and mission and to innovate every time to improve the quality of the effectiveness of undergraduate schools. A conducive undergraduate school climate will be realized if the chancellor and all faculty leaders and department heads work together in one voice and one goal to solve the problems that occur. With the process as above, the effectiveness of undergraduate schools can carry out its vision and mission well and produce quality educational processes and outputs.

Maintaining a climate of security and order for students. To achieve an effective undergraduate school, maintaining a climate of security and order within the undergraduate school environment is necessary. The undergraduate school climate that is maintained will lead to a high enthusiasm for learning. The spirit of fair competition among students towards achievement will increase by itself. To maintain a climate of security and order, the most important thing is the example of leaders from the university level to study programs/majors as leaders of undergraduate school organizations, as well as lecturers as leaders in conducting lectures in class. Leaders of undergraduate schools must be able to be pioneers in terms of example and integrity must also be able to transmit the exemplary possessed to the dossiers which will eventually be made an example by students in their behavior in maintaining undergraduate school climate.

Besides, a clear rule system and strict application are needed to deal with student behavior that is not good. Leaders in undergraduate schools and assisted by lecturers must be able to formulate and apply the right rules for every violation committed by students.

Supervision of student progress, Supervision of learners is needed to achieve an effective undergraduate school. Supervision will be very useful to find out the potential and development of student quality so that if there is anything unusual about student development, an immediate decision can be taken so that it does not lead to negative things. Supervision of students should be done continuously in a period that is not too long. This is intended so that if there are irregularities in the development of students can be immediately dealt with causing problems that occur. Besides, such supervision also spurs students to always be motivated to develop their potential. 
High expectations, High expectations referred to here are positive expectations that arouse students' motivation in obtaining targeted achievements. High expectations are expected to provide motivation and confidence. This high expectation naturally arises when undergraduate schools are effective and have a good track record in the eyes of the community. Effective undergraduate schools like this are required to be able to manage the expectations of many of its users, so as not to burden the community. Meanwhile, if undergraduate schools do not have such expectations, then policymakers at undergraduate schools should build continuously the reputation of undergraduate school institutions that can give trust to the user community.

An effective undergraduate school development model can also be examined based on systems approach techniques ranging from inputs (to school effectiveness study); processes/throughputs; outputs (of school effectiveness study); and outcomes (longer-term results of study). There are various guidelines for effective undergraduate schools to be able to live and compete with other undergraduate schools by (a) continuously innovating to develop the creativity of students, employees and various services in undergraduate school institutions; (b) adopting a new philosophy, by making quality a new philosophy and paradigm with an emphasis on the quality of learning and the quality of undergraduate schools; (c) stop relying on mass inspections, it must be ensured that educators/lecturers must produce good quality performance; (d) approach parents or other undergraduate schools to ensure the quality of inputs; (e) carry out continuous evaluation and research to develop systems and processes as well as quality and productivity development; (f) conducting training and retraining of total quality for lecturers, students, faculty / staff / employees. The lecturers are the main characters in the model of quality with the development of the ability to control themselves, decision making and problem-solving; (g) rector, dean and chairman of the department/study programs in undergraduate school as a leader to direct the faculty students in the learning process, (h) all employees must feel they can show or explain various problems encountered and find ways of development. In class, lecturers must develop a culture of good communication with students; (i) the entire academic community must work following the policies and objectives of undergraduate school institutions. It is necessary to remove the barriers between various departments and employees and among students; (j) reducing various slogans, pressures and targets that are based on coercion from outside; (k) reduce the quota figures, replaced with the application of leadership, because the determination of quotas would actually reduce productivity and quality; (1) remove any obstacles that could eliminate the pride of the leadership, staff and students shaddap performance skills; (m) provide educational or personal development programs for everyone in line with the needs and mastery of new materials, methods and techniques; and (n) managers must provide the opportunity for all parties to take part or role in achieving the quality of ongoing undergraduate school effectiveness.

\section{Conclusion}

The conclusion of the previous findings, this study draws conclusions as follows: "Undergraduate school culture, leadership patterns and interpersonal communication influence directly or indirectly through trust and commitment built by all undergraduate school personnel on program planning, implementation of work plans, supervision and evaluation, undergraduate school leadership, management information systems as a manifestation of undergraduate schools effective, efficient and sustainable". 


\section{References}

Arikunto, S. (2000). Manajemen Pembelajaran, Jakarta: Rineka Cipta.

Baran. Stanley, J. (2004). Introduction to Mass Communication. New York: Mc Graw Hill.

Fiedler, F. E. and Charmers, M.M. (1974). Leadership and Effective Management. Glenview Illionis: Scott, Foresman and Company.

Gribbin, A. (1992). Reeventing Leadership, Terjemahan Asril Mardjohan, Jakarta: Inter Aksara, 1992 Hadiyanto. (2004). Mencari Sosok Desentralisasi Manajemen Pendidikan di Indonesia. Jakarta:

Rineka Cipta,

Hersey, P. and Blancard, K.H. (1988). Management of Organization Behavior, London; Prentice Hall, Inc.

Hoy W.K. and Miskel, CG. (1998). Educational Administration, Theory, Research and Practice, New York: Random House, Inc.

James A.F Stoner and R, Edward Freeman. (1992). Managemen. (Jakarta: Intermedia, alih bahasa: Wehelmus $\mathrm{W}$ et al.

Johnson, David W., \& Frank P. (2009). Johnson.Joining together: Group theory and group skills. 10th ed. Upper Saddle River, NJ: Pearson Education.

Kim, D. J., Lee, Ferrin, D. L., and Rao, H. R. (2003). Antecendents of Consumer Trust in B-to-C Electronic Commerce, Proceedings of Ninth Americans Conference on Information Systems,pp. 157-167

Komariah, A. and Triatna, C. (2006). Visionary Leadership Menuju Sekolah Efektif, Jakarta: Bumi Aksara.

Koontz, H. et.al. (1984). Management a System and Contigency Analysis of Managerial Function, Tokyo: Megraw Hill, Kogakusha.

Luthan, F. (2006). Organizational Behavior. 10th Edition. Alih Bahasa: Yuwono, V.A dkk.

Yogyakarta; Andi Offset.

Mayer, R.C., Davis, J. H., and Schoorman, F. D. (1995). An Integratif Model of Organizational Trust, Academy of Management Review. 30 (3): 709-734.

Moedjiarto. (2002). Sekolah Unggul Metodologi Untuk Meningkatkan Mutu Pendidikan, Jakarta: Duta Pustaka.

Morgan, Robert M and Shelby D Hunt. (1994). "The Commitment Trust of Relationship Marketing", Journal of Marketing. Vol 58,. p 20-38

Pavlou, P. A., dan Gefen, D. (2002). Building Effective Online Marketplaces with Institutionbased Trust, Proceedings of Twenty-Third International Conference on Information Systems, PP. 667-675

Rosseau et al. (1998). Not So Different After All: A Cross-Discipline View of trust. Academy of Management Review. 23 (3), 393-404.

Sagala, S. (2005). Manajemen Berbasis Sekolah Dan Masyarakat Strategu Memenangkan Persaingan Mutu. Jakarta; Nimas Multima,

Sarah Trenholm. (1991). Human Communication Theory,. Englewood Cliffs, New Jersey, Prentice Hall, Inc,.

Slocum/Hellriegel. (2009). Principles Of Organizational Behavior, Twelfth Edition

Stephen W. Littlejogn. (1991). Theories og Human Communication, (Dalifornia: Wadsworth Publishing Company.

Taylor, S.E., Peplau, L.A., and Sears, D.O. Social Psychology. (2009). 12th Edition. Alih

Bahasa: Tri Wibowo B.S. Jakarta: Prenada Media Group.

Taylor, B. and Bullard. P. (1990). Unusually Effective School, Center for Effective Schools, CCE 


\section{Oklahoma University.}

Terry, G.R. (1983). Principles of Management. Seventh Edition. Alih Bahasa: Winardi, Bandung; Alumni.

Wahyusumidjo. (2002). Kepemimpinan Kepala Sekolah, Jakarta; Rajagrafindo Persada,

Yukl, G.A. Leadership In Organization, Kepemimpinan Dalam Organisasi, Edisi Kelima Alih Bahasa: Budi Supriyanto. Jakarta: Indeks, 2009. 